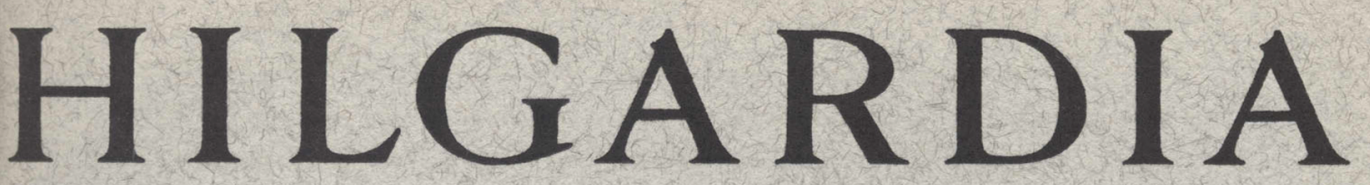

A Journal of Agricultural Science Published by the California Agricultural Experiment Station

\title{
FACTORS INFLUENCING CONTROL OF THE CITRUS NEMATODE IN THE FIELD WITH D-D
}

R. C. BAINES, F. J. FOOTE, L. H. STOLZY, R. H. SMALL, and M. J. GARBER

UNIVERSITY OF CALIFORNIA - BERKELEY, CALIFORNIA 
When replanting citrus nematode-infested soil with susceptible crops, it usually is important to treat the soil with a 1,3-dichloropropene or other type of chemical for control of this nematode (Tylenchulus semipenetrans Cobb). Since the degree of control of the citrus nematode often is unsatisfactory, an effort was made to develop improved and highly effective methods for applying D-D type chemical in the field. The vertical diffusion pattern and efficacy of D-D for control of the citrus nematodes in a number of Yolo loam and silt loam soils were determined. When the D-D was applied at rates of $60,90,120$, and 180 gallons per acre, 100 per cent of the citrus nematodes in the top 3 to 5 feet of soil frequently were killed. The amount of the chemical applied and the soil type treated affected greatly the degree of control. The effect of placement depth of the D-D in the soil, moisture content of the soil, time of year applied, and of some post-irrigation treatments on control were determined. 


\title{
H $\quad I \quad L \quad G \quad A \quad R \quad D \quad I \quad A$
}

A Journal of Agricultural Science Published by

the California Agricultural Experiment Station

VoL. 29

NOVEMBER, 1959

No. 8

\section{FACTORS INFLUENCING CONTROL OF THE CITRUS NEMATODE IN THE FIELD WITH D-D'}

\author{
R. C. BAINES, ${ }^{2}$ F. J. FOOTE, ${ }^{3}$ L. H. STOLZY, ${ }^{4}$ R. H. SMALL, ${ }^{5}$ and M. J. GARBER ${ }^{8}$
}

\section{INTRODUCTION}

The Citrus nematode (Tylenchulus semipenetrans Cobb) frequently occurs at depths of 8 or more feet in California soils. When planting susceptible crops, it is highly desirable to kill the nematode in the soil that the roots of the future trees or vines might occupy. The 1,3-dichloropropene types of nematocides were reported by Baines et al. $(1956)^{7}$ to be effective for control of this nematode. Dosages for different soil types and methods of application also were suggested. However, additional information on the effect of methods of application on the diffusion pattern and control of the citrus nematode in fine-textured soils in the field was needed, since control of the nematode in the subsoil sometimes was unsatisfactory even when relatively high doses of D-D ${ }^{8}$ were applied. Considerable fundamental information of factors affecting the diffusion of a number of chemicals in soils is available. Carbon disulfide was shown by Higgins and Pollard (1937) to diffuse chiefly downward and laterally in a number of soils. Diffusion was greatest in dry soil and increased doses did not change the rate nor direction of diffusion. Hagan (1941) and Hannesson (1945) also found that carbon disulfide diffused most rapidly in dry soil and that the rate of diffusion decreased with increase in soil moisture. In wet fine-textured clay loam soils diffusion rate was nearly zero. Diffusion rate was related to the free porosity of the soil. Hanson and Nex (1953) found that porosity or total gas space was most important in the movement of ethylene dibromide through mineral soils. Increasing moisture or packing of the soil decreased porosity which, in turn, decreased diffusion

${ }^{1}$ Received for publication January 27, 1959.

${ }^{2}$ Plant Nematologist, Citrus Experiment Station, Riverside.

${ }^{3}$ Director of Research, Limoneira Company, Santa Paula, California.

${ }^{4}$ Assistant Irrigation Engineer, Citrus Experiment Station, Riverside.

${ }^{5}$ Laboratory Technician II, Citrus Experiment Station, Riverside.

${ }^{8}$ Assistant Biometrician, Citrus Experiment Station, Riverside.

"See "Literature Cited" for citations referred to in the text by author and date.

${ }^{8} \mathrm{D}$-D is a mixture containing 97 per cent of 1,2-dichloropropane and 1,3-dichloropropene and 3 per cent of other chlorinated hydrocarbons. It is manufactured by the Shell Chemical Company. 
rate. They reported that ethylene dibromide was adsorbed strongly on soils at moisture content below the wilting point, that at higher soil moisture movement was good in spite of lower porosity, presumably because of the slight solubility of the chemical in water. Rate of diffusion was markedly decreased at lower temperatures. The effect of a number of factors on control of the root-knot nematode with ethylene dibromide was reported recently by Goring and Youngson (1957). They found that control was difficult in the surface 3 inches of soil, because of rapid diffusion of ethylene dibromide to the atmosphere. Schmidt (1947) reported that movement of D-D vapor is most rapid in a pineapple lateritic soil of medium-moisture content, less rapid in a dry soil, and least rapid in a very dry soil. He found that retention time of vapors in the soil followed the same order. Siegel et al. (1951) reported that 1,3-dichloropropene was highly sorbed in soils high in organic matter. Allen and Raski (1950) determined the diffusion pattern of D-D in six soil types. They found that D-D diffused well in a sandy loam and fine sandy loam soil, and moderately well in a silt loam and clay loam soil. In a clay and an organic loam soil the chemical diffused poorly, or 2 to 4 inches in a lateral direction when $2.15 \mathrm{ml}$ of the chemical were placed at an injection point. It was about 100 times more effective for control of the root-knot nematode in a sandy loam than in a clay or organic loam soil.

The present investigations concerning the effectiveness of D-D applied by different methods are an attempt to develop highly effective methods of application of D-D for control of the citrus nematode, especially in the subsoil. Some data of the influence of dosage, depth of injection, moisture content and temperature of the soil, irrigation, and soil type on control of the citrus nematode with D-D are presented herein. All of the tests were made in fields. The information on control is pertinent for the soils or soils similar to those of the tests; however, data on diffusion of D-D in the soils and on the degree of control obtained with the different methods of application likely would find wider use.

\section{METHODS}

All of the tests were made in deep, well-drained Yolo loams and silt loams on the property of the Limoneira Company near Santa Paula. The Yolo soils are formed from transported material derived originally from sandstone and shales, with mixtures from other sources. The flood plains and confluent fans occupied by these soils make up broad alluvial plains. The soils have been rapidly built up by the deposition of alluvial material in the valleys by minor streams. Weathering is relatively slight and the entire profile is without structural development. They are nearly neutral and the organic matter content is low. The surface is brown, being darker than the subsoil. The diffusion tests were made on soils 20 to 30 feet or more deep and which showed some stratification.

Physical properties were determined on soil samples taken in the different soil horizons at representative locations (tables 1 to 5). Particle size distributions were determined with the hydrometer method described by Day 
(1950). The average clay content of the top 5 feet of the soils ranged from 13.7 per cent to 27.2 per cent, silt from 48.1 per cent to 57.1 per cent, and sand from 19.4 per cent to 35.2 per cent. Bulk density values and per cent moisture by weight $(\mathrm{PW})$ at $1 / 3$-bar suction were determined on nonfragmented soil cores.

TABLE 1

PARTICLE SIZE ANALYSIS AND MOISTURE PROPERTIES OF A YOLO SILT LOAM SOIL IN FIELD A

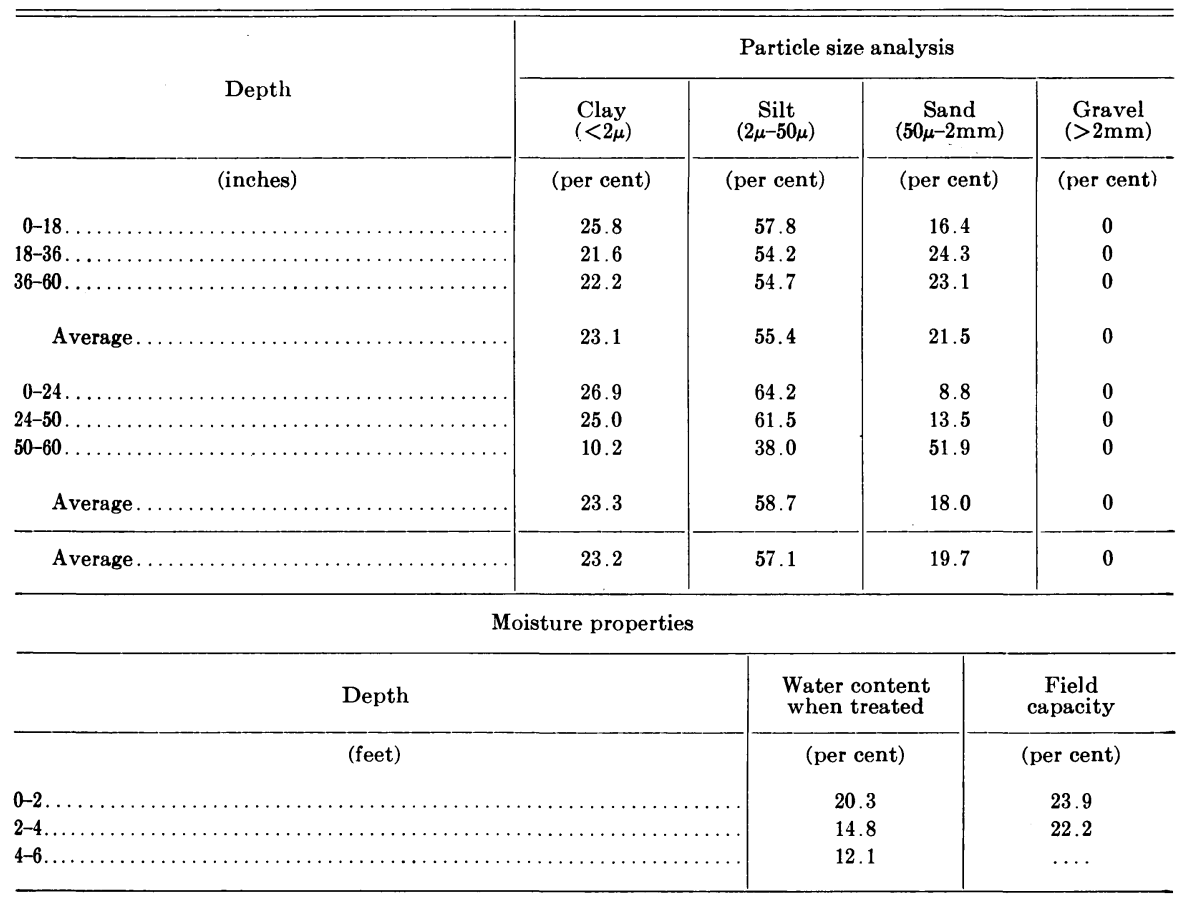

The soils were tilled to depths of 8 to 14 inches and the surface 4 to 5 inches were in good tilth at the time of treating. The D-D was applied with hand-operated probe type of applicators and with conventional chisel type applicators mounted on either a Caterpillar or Ford tractor (fig. 1). Following injection with the tractor equipment the surface of the soil was dragged and then rolled two or more times with a cultipacker. When hand-operated equipment was used the probe holes were closed by pressure of a shoe heel. Supplementary treatments then were made in some of the tests.

Soil samples for determination of viable citrus nematode larvae were taken with soil tubes 1 inch in diameter. Four soil cores were taken per plot. The soil passed through an eighth-inch-mesh sieve and then two 50 ce samples were placed on modified Baermann funnels (fig. 2).

In all of the tests described below, the D-D was applied on a pattern over the plots. The loci of placement of the chemical were spaced so that in all 


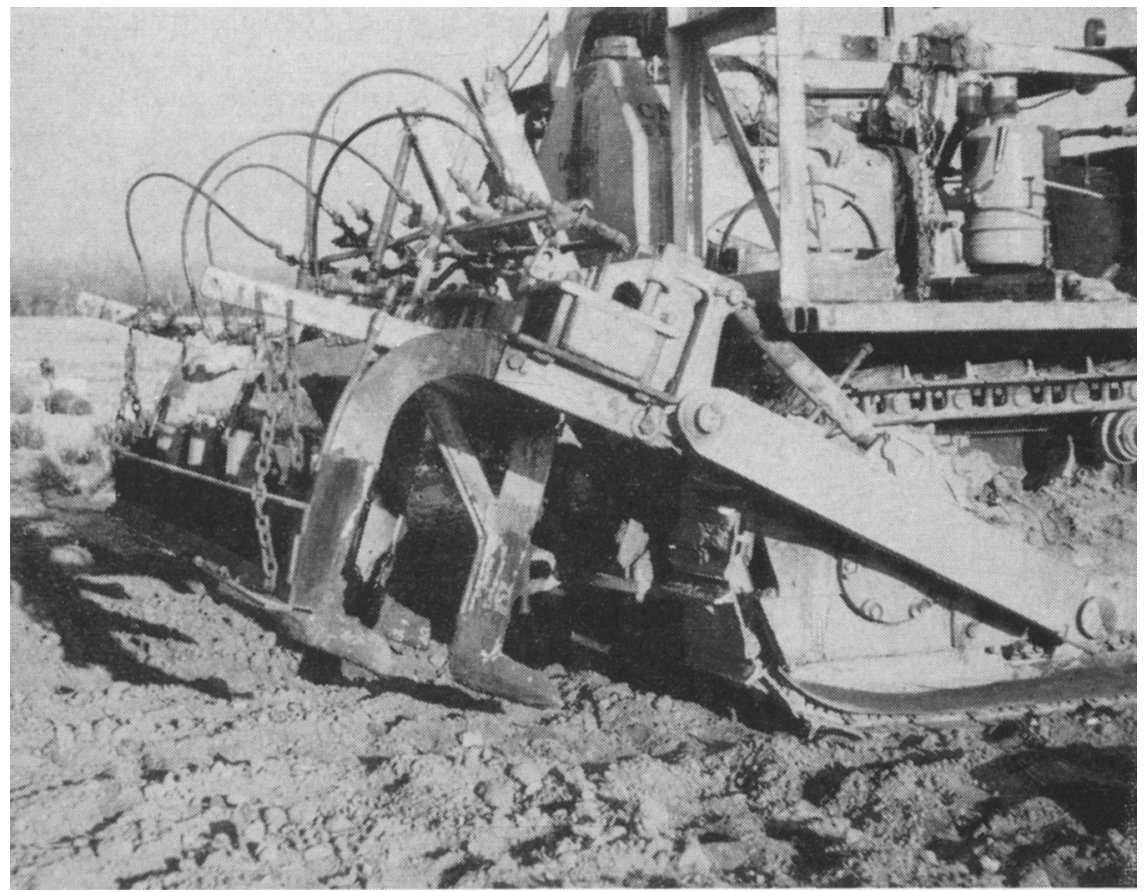

Fig. 1. A heavy-duty chisel type of applicator is used to apply D-D at depths of 12 to 18 inches in many of the tests.

TABLE 2

PARTICLE SIZE ANALYSIS AND PHYSICAL AND MOISTURE PROPERTIES OF A YOLO LOAM SOIL IN FIELD B

\begin{tabular}{|c|c|c|c|c|c|c|}
\hline Depth & $\underset{(<2 \mu)}{\text { Clay }}$ & $\underset{(2 \mu-50 \mu)}{\operatorname{Silt}}$ & $\underset{(50 \mu-2 \mathrm{~mm})}{\text { Sand }}$ & $\begin{array}{c}\text { Gravel } \\
(>2 \mathrm{~mm})\end{array}$ & $\underset{\text { density }}{\text { Bulk }}$ & $\begin{array}{l}\mathrm{PW} \text { at } 1 / 3 \mathrm{bar} \\
\text { suction }\end{array}$ \\
\hline (inches) & (per cent) & (per cent) & (per cent) & (per cent) & $\mathrm{gm} / \mathrm{cc}$ & (per cent) \\
\hline $0-16 \ldots \ldots \ldots \ldots \ldots \ldots$ & 10.7 & 45.0 & 44.4 & 3.6 & 1.40 & 17.0 \\
\hline $16-24 \ldots \ldots \ldots \ldots \ldots \ldots \ldots$ & 17.0 & 66.2 & 16.8 & 1.0 & 1.22 & 22.9 \\
\hline $24-36 \ldots \ldots \ldots \ldots \ldots \ldots \ldots$ & 11.1 & 42.5 & 46.4 & 1.2 & 1.32 & 20.2 \\
\hline $36-42 \ldots \ldots \ldots \ldots \ldots \ldots \ldots$ & 17.7 & 73.7 & 8.6 & 0.5 & 1.20 & 26.6 \\
\hline $42-53 \ldots \ldots \ldots \ldots \ldots \ldots \ldots$ & 13.9 & 62.3 & 23.8 & 0.2 & 1.32 & 20.9 \\
\hline $53-60 \ldots \ldots \ldots \ldots \ldots \ldots$, & 25.8 & 60.1 & 14.1 & 0.7 & $\cdots$ & $\cdots$ \\
\hline $60-64 \ldots \ldots \ldots \ldots \ldots \ldots$ & 15.0 & 38.1 & 46.9 & 2.1 & $\cdots$ & $\cdots$ \\
\hline Average....... & 14.7 & 54.1 & 31.2 & 1.5 & $\cdots$ & $\cdots$ \\
\hline $0-15 \ldots \ldots \ldots \ldots \ldots \ldots$ & 12.4 & 40.5 & 47.1 & 8.4 & $\ldots$ & $\ldots$ \\
\hline $15-20, \ldots \ldots \ldots \ldots \ldots \ldots$, & 15.7 & 54.0 & 30.3 & 0.7 & $\cdots$ & $\cdots$ \\
\hline $20-30, \ldots \ldots \ldots \ldots \ldots \ldots \ldots$ & 12.0 & 48.5 & 39.5 & 5.0 & $\cdots$ & $\cdots$ \\
\hline $30-46 \ldots \ldots \ldots \ldots \ldots \ldots \ldots$ & 12.0 & 44.8 & 43.2 & 4.1 & $\cdots$ & $\cdots$ \\
\hline $46-57 \ldots \ldots \ldots \ldots \ldots \ldots \ldots$ & 12.0 & 53.9 & 34.2 & 1.7 & $\cdots$ & $\cdots$ \\
\hline $57-60 \ldots \ldots \ldots \ldots \ldots \ldots \ldots$ & 7.8 & 34.0 & 58.2 & 0.5 & $\ldots$ & $\cdots$ \\
\hline $60-64 \ldots \ldots \ldots \ldots \ldots \ldots \ldots$ & 19.9 & 76.0 & 4.1 & 0.1 & $\cdots$ & $\cdots$ \\
\hline Average......... & 12.7 & 48.1 & 39.2 & 4.3 & $\cdots$ & $\cdots$ \\
\hline Average........ & 13.7 & 51.1 & 35.2 & 2.9 & $\cdots$ & $\cdots$ \\
\hline
\end{tabular}

* $\mathrm{PW}=$ Per cent moisture by weight when subjected to $1 / 3$ bar suction.

Note: The top 2 feet of soil contained 9.5 per cent water; the 2- to 4 -foot horizon, 8.0 per cent; and the $4-$ to 8-foot:depth 13.8 per cent when treated on $11 / 30 / 55$. 
TABLE 3

FARTICLE SIZE ANALYSIS AND PHYSICAL AND MOISTURE PROPERTIES OF A YOLO LOAM SOIL IN FIELD C

\begin{tabular}{|c|c|c|c|c|c|c|}
\hline Depth & $\underset{(<2 \mu)}{\text { Clay }}$ & $\begin{array}{c}\text { Silt } \\
(2 \mu-50 \mu)\end{array}$ & $\underset{(50 \mu-2 \mathrm{~mm})}{\text { Sand }}$ & $\begin{array}{c}\text { Gravel } \\
(>2 \mathrm{~mm})\end{array}$ & $\underset{\text { density }}{\text { Bulk }}$ & $\begin{array}{l}\text { PW at } 1 / 3 \text { bar } \\
\text { suction* }\end{array}$ \\
\hline (inches) & (per cent) & (per cent) & (per cent) & (per cent) & $\mathrm{gm} / \mathrm{cc}$ & (per cent) \\
\hline $0-10$ & 14.8 & 48.5 & 36.6 & 1.9 & 1.44 & 18.6 \\
\hline $10-27$. & 20.8 & 50.9 & 28.3 & 2.4 & 1.22 & 21.9 \\
\hline $27-37 \ldots$ & 20.8 & 58.7 & 20.5 & 1.3 & 1.21 & 22.1 \\
\hline $37-53 \ldots$ & 15.0 & 48.8 & 36.2 & 1.9 & 1.38 & 16.8 \\
\hline $53-64$. & 24.7 & 58.7 & 16.6 & 1.2 & 1.34 & 20.4 \\
\hline Average... & 19.1 & 52.6 & 28.3 & 1.82 & $\cdots$ & ... \\
\hline
\end{tabular}

* Per cent moisture by weight.

Note: The soil contained 16 per cent water in the $0-48^{\prime \prime}$ depth when treated on $5 / 26 / 55$.

TABLE 4

PARTICLE SIZE ANALYSIS OF A YOLO SILT LOAM SOIL IN FIELD D

\begin{tabular}{|c|c|c|c|c|}
\hline Depth & $\begin{array}{l}\text { Clay } \\
(<2 \mu)\end{array}$ & $\begin{array}{c}\text { Silt } \\
(2 \mu-50 \mu)\end{array}$ & $\begin{array}{c}\text { Sand } \\
(50 \mu-2 \mathrm{~mm})\end{array}$ & $\begin{array}{c}\text { Gravel } \\
(>2 \mathrm{~mm})\end{array}$ \\
\hline (inches) & (per cent) & (per cent) & (per cent) & (per cent) \\
\hline $0-12$. & 21.9 & 50.2 & 27.9 & 5.6 \\
\hline $12-24 .$. & 31.7 & 57.8 & 10.5 & 0.7 \\
\hline $24-36 \ldots$ & 29.6 & 46.2 & 24.2 & 1.7 \\
\hline $36-48$. & 26.9 & 50.9 & 22.2 & 2.5 \\
\hline $48-60 \ldots \ldots \ldots \ldots$ & 26.0 & 62.2 & 11.9 & 0.0 \\
\hline Average. & 27.2 & 53.4 & 19.4 & 2.1 \\
\hline
\end{tabular}

TABLE 5

PARTICLE SIZE ANALYSIS OF A YOLO LOAM SOIL IN FIELD E

\begin{tabular}{|c|c|c|c|c|}
\hline Depth & $\underset{(<2 \mu)}{\text { Clay }}$ & $\begin{array}{c}\text { Silt } \\
(2 \mu-50 \mu)\end{array}$ & $\underset{(50 \mu-2 \mathrm{~mm})}{\text { Sand }}$ & $\begin{array}{c}\text { Gravel } \\
(>2 \mathrm{~mm})\end{array}$ \\
\hline (inches) & (per cent) & (per cent) & (per cent) & (per cent) \\
\hline $0-12 \ldots$ & 14.9 & 36.3 & 48.8 & 4.6 \\
\hline $12-24 \ldots \ldots \ldots \ldots \ldots$ & 17.9 & 47.2 & 34.9 & 2.3 \\
\hline $24-36 \ldots \ldots \ldots \ldots \ldots$ & 15.8 & 49.4 & 34.8 & 5.2 \\
\hline $36-48 \ldots \ldots \ldots \ldots$ & 17.8 & 53.4 & 28.8 & 2.3 \\
\hline $48-60 \ldots \ldots \ldots \ldots \ldots \ldots \ldots \ldots \ldots \ldots \ldots \ldots \ldots$ & 21.8 & 50.2 & 28.0 & 0.6 \\
\hline Average...$\ldots \ldots \ldots \ldots \ldots \ldots \ldots$ & 17.7 & 47.3 & 35.0 & 3.0 \\
\hline 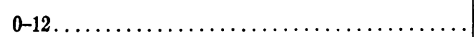 & 18.9 & 48.1 & 33.0 & 10.7 \\
\hline $12-24 \ldots \ldots \ldots \ldots \ldots \ldots \ldots \ldots \ldots \ldots \ldots \ldots$ & 17.9 & 49.1 & 33.0 & 14.6 \\
\hline $24-36 \ldots \ldots \ldots \ldots \ldots \ldots \ldots \ldots \ldots \ldots \ldots \ldots \ldots$ & 17.8 & 48.8 & 33.4 & 12.1 \\
\hline $36-42 \ldots \ldots \ldots \ldots \ldots$ & 17.8 & 46.8 & 35.4 & 6.6 \\
\hline $42-60 \ldots \ldots \ldots \ldots \ldots$ & 17.7 & 52.0 & 30.3 & 7.5 \\
\hline Average... & 18.0 & 49.0 & 33.0 & 10.3 \\
\hline Average. & 17.9 & 48.1 & 34.0 & 6.7 \\
\hline
\end{tabular}




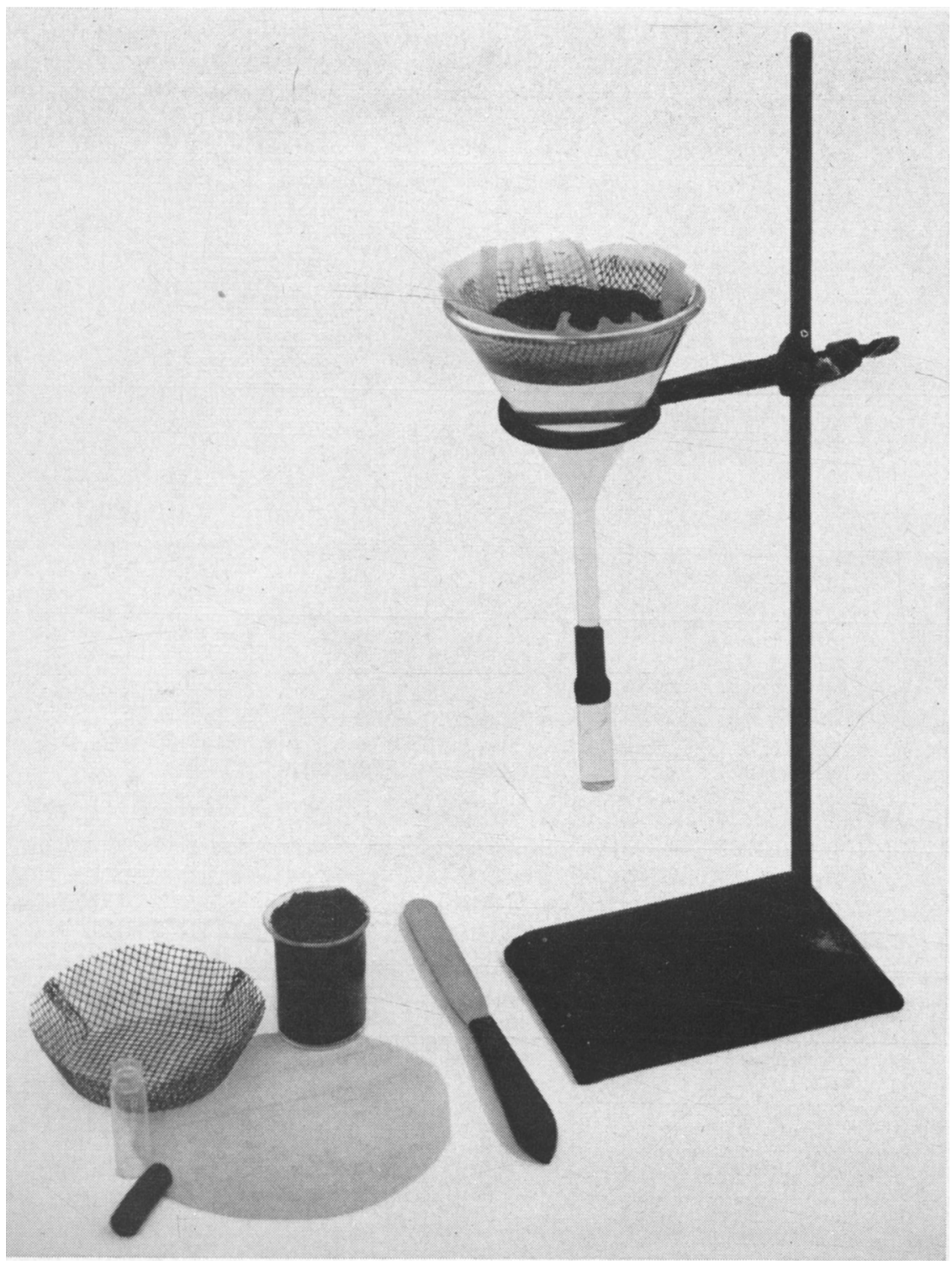

Fig. 2. Type of "Baermann" funnel used to obtain active citrus nematode larvae from soil. A small vial containing water is slipped over the stem of the funnel and secured with a piece of rubber tubing. Then the funnel is nearly filled with tap water. The soil sample is passed through a $1 / 8$-inch mesh sieve, then 50 ce of the soil is placed in a wire basket which is lined with tissue paper. The basket of soil is gently placed in the top of the funnel and water is added as needed to maintain the level of the water even with the surface of the soil. After 48 hours at a temperature of $70^{\circ}$ to $75^{\circ} \mathrm{F}$ the vial is removed and the nematodes counted. 
cases vapors from two or more loci overlapped. The term "diffusion pattern" in the text below thus refers to the diffusion of D-D mainly in a vertical direction.

\section{CONTROL WITH THREE DOSES OF D-D ON A SILT LOAM SOIL IN FIELD A}

The effectiveness of 60,120 , and 180 gallons of D-D per acre for control of the citrus nematode was determined on a Yolo silt loam, from which lemon trees recently had been removed. This soil was free of compacted layers, but

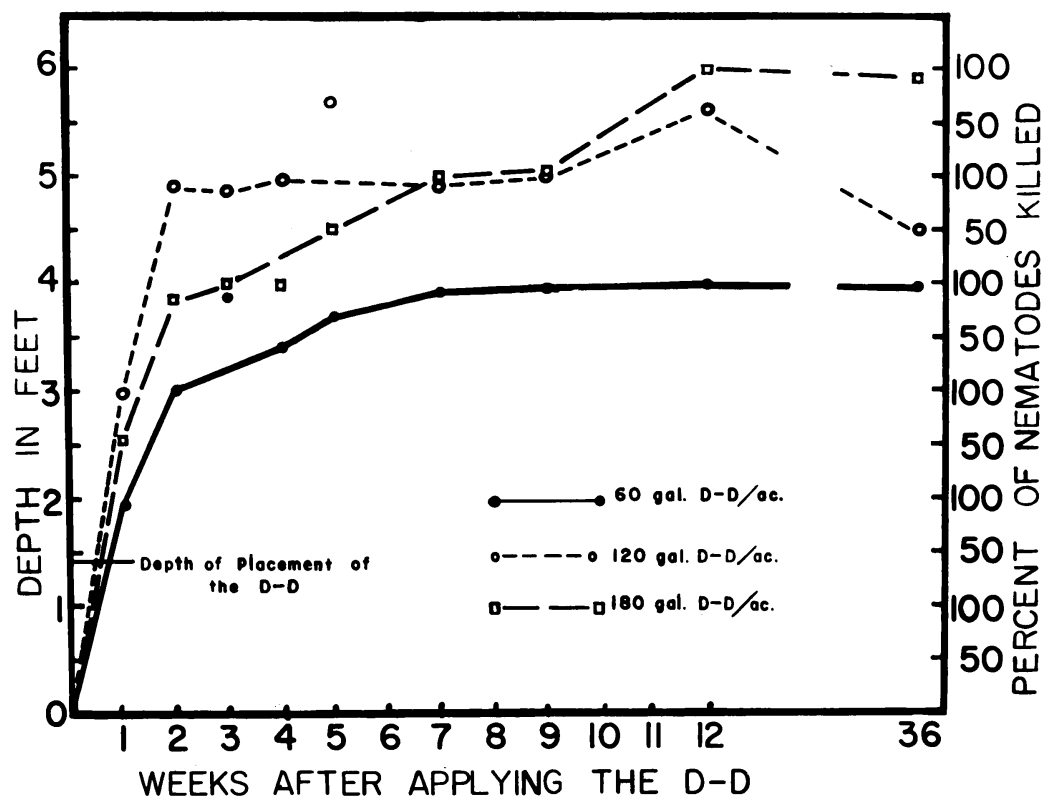

Fig. 3. Rate of diffusion and kill of the citrus nematode with three doses of D-D in a silt loam soil. D-D at doses of 60, 120, and 180 gallons per acre was applied 14 inches deep in bands 22 inches apart.

contained some strata high in clay (table 1 ). The top 5 feet of soil contained 23.2 per cent clay, 57.1 per cent silt, and 19.7 per cent sand. It was chiseled to a depth of 18 inches, then plowed, irrigated, disked, and harrowed. The D-D was applied at a depth of 13 to 14 inches by chisels 21 inches apart. The water content of the top 2 feet of soil was slightly below, and that of the 2- to 4 -foot depth was at $2 / 3$ field capacity. Eight days after treating, 1.6 inches of rain increased the moisture of the top 2 feet or more of soil to field capacity. Soil samples for determining nematodes were taken frequently during the three months after application of the D-D. Data of the number of citrus nematodes obtained from the soil and the diffusion patterns are presented in table 6 and figure 3.

Diffusion of the D-D was most rapid during the first two weeks. At that 
time 100 per cent of the citrus nematodes in the top 3 feet of soil were killed when 60 gallons of D-D per acre were applied. All $^{\circ}$ of the citrus nematodes in the first 4 feet of soil and 90 per cent of those in the fifth foot were killed when 120 gallons, of D-D per acre were applied. The 180 gallons per acre dose killed all of the citrus nematodes in the top 3 feet of soil, and 85 per cent of those in the fourth foot.

Maximum control, or downward diffusion of lethal concentrations of the D-D, was reached after three months for the 60-, 120-, and 180-gallon doses.

TABLE 6

CONTROL OF THE CITRUS NEMATODE WITH DIFFERENT DOSES

OF D-D IN A SILT LOAM SOIL IN FIELD A*

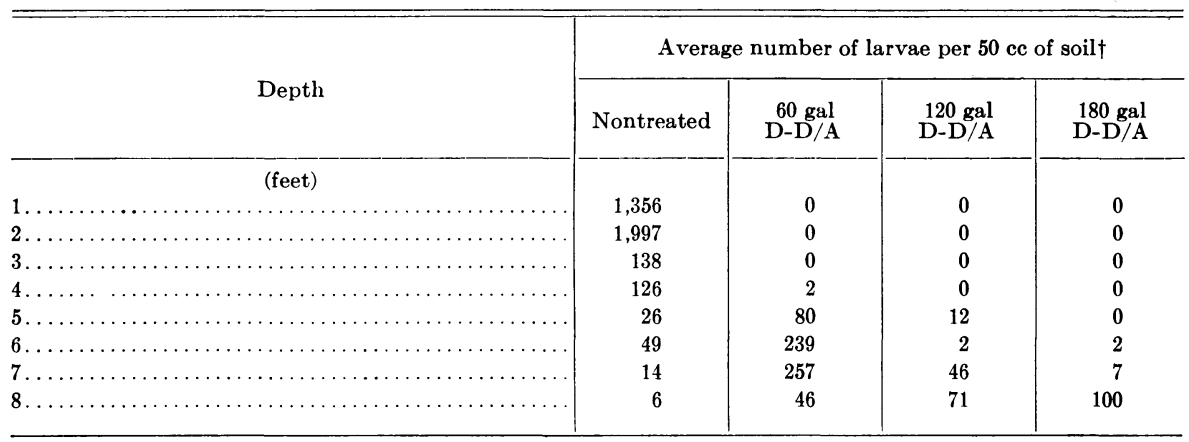

* The D-D was applied 11/3/53 at a depth of 14 to 15 inches with chisels 21 inches apart. The plots were sampled $7 / 22 / 54$ and $8 / 11 / 54$ (eight and nine months after treating).

$\dagger$ The figures are the average for two plots.

The 60-gallons-per-acre dose killed all of the citrus nematodes in the top 3 feet of soil and 98 per cent of those in the fourth foot. This dose apparently did not kill nematodes occurring below 4 feet in the soil. One hundred twenty gallons of D-D per acre killed all of the citrus nematodes in the top 4 feet of soil, and 50 per cent of those in the fifth foot. All of the citrus nematodes in the top 5 feet of soil and 92 per cent of those in the sixth foot were killed when 180 gallons of D-D per acre were applied. Thus, with increase in dose of the D-D, lethal concentrations of the chemical occurred at greater depths in the soil from the point of placement of the chemical.

"In this paper "all" connotes 100 per cent of the citrus nematode larvae in the samples examined. Lemon trees on sweet orange rootstock (citrus nematode susceptible), which were planted five months after applying the D-D in field "A," were examined for citrus nematodes after they had grown for four years. Soil and root samples were taken close to the trees. The citrus nematode-infestation patterns on the different soil fumigation treatments were similar to those observed earlier and reported in this paper. In the later sampling, 14 nonfumigated plots and a similar number of each D-D treatments were examined. All of these plots were not examined in the earlier sampling, since many of them had been subject to different crop rotations and contained lower levels of infestation than the nonrotated plots. However, all of the plots contained numerous citrus nematode larvae in the top 4 feet of soil when the D-D treatments were applied. The number and distribution of citrus nematode larvae in the soil about the four-year-old trees verify the findings of the earlier samplings and also indicate that the citrus nematode larvae move slowly through this Yolo silt loam soil. 
Control three months after treating appeared to be superior to that after nine months. The observed changes in numbers of nematodes obtained is believed to be due to recovery or increased motility of a few nematodes which had absorbed sublethal amounts of the toxicant, but could be caused by uneven diffusion of the chemical through the soil at deeper depths. However, a somewhat similar increase in numbers of active citrus nematodes also has been observed in a greenhouse test with D-D in 5-gallon pots of soil.

\section{CONTROL WITH D-D UNDER POLYETHYLENE PLASTIC TARP}

After D-D is applied by means of power equipment in the field the surface of the soil usually is compacted by means of a drag and then cultipacked thoroughly. These operations increase the bulk density of the surface soil, which retards diffusion of the chemical to the atmosphere. The relative effectiveness of such practices and the pattern of control when loss of D-D from the surface was negligible, were determined in a Yolo loam soil, of field B. This soil contained an average of 13.7 per cent clay, 51.1 per cent silt, and 35.2 per cent sand, in the top 5 feet of soil, table 2. The moisture in the 1- to 4 -foot horizon of soil had been depleted by a previous crop of lima beans and was slightly above the wilting point. However, the first foot of soil had been moistened by 0.47 inch of rain which occurred eight to thirteen days before treating. The top 2 feet of soil contained approximately 9.5 per cent water, the 2- to 4-foot horizon, 8.0 per cent, and the 4- to 8 -foot depth, 13.8 per cent.

D-D at rates of 60,90 , and 120 gallons per acre was applied 14 inches deep by chisels 22 inches apart. Then a cultipacker was pulled over the surface of the soil three or four times. Gas-proof polyethylene plastic tarps were placed on plots that were treated with 60 gallons of D-D per acre. The edges of the tarps were placed in shallow trenches and back-filled. Each plot was 24 feet square, except those covered with the tarps, which were 16 feet square. The treatments were replicated four times. The numbers of citrus nematodes obtained three months after treating are presented in table 7.

The 60 gallons of D-D per acre treatment killed 99 per cent, 100 per cent, and 97 per cent, respectively, of the citrus nematodes in the 0 to 2-, 2- to 4-, and 4- to 6-foot horizons. The 90-gallon-per-acre treatment killed all of the citrus nematodes in the 0 to 4 -foot, and 98 per cent of those in the 4- to 6 -foot depths. All of the citrus nematodes in the 0 to 6 -foot depth were killed when the soil was treated with 120 gallons of D-D per acre, and when treated with 60 gallons of D-D per acre and then covered with a plastic tarp. The number of larvae found at the 6- to 8-foot depth was highly variable for most of the treatments, and the differences observed are not necessarily due to the treatments.

A strong odor of D-D was noticed when the plastic tarps were removed three and one-half months after applying the chemicals. No detectable D-D odor occurred on any of the noncovered plots. Since the tarps prevented loss of the D-D to the atmosphere, slight or no diffusion gradient toward the surface occurred after the concentration of D-D reached equilibrium in the 
surface soil. $A$ high concentration of D-D in the zone of injection likely occurred for a longer period and thus resulted in more D-D diffusing into the soil at deeper depths than on the noncovered areas. The superior control of nematodes in the 0 to 2 -foot and 4 - to 6 -foot horizons when the soil was covered with a gas-proof tarp indicated that considerable amounts of D-D diffused from the surface of the noncovered soil, even though it was cultipacked or rolled thoroughly.

TABLE 7

EFFECTIVENESS OF THREE DOSES OF D-D FOR CONTROL OF THE CITRUS NEMATODE AND THE EFFECT OF POST-

TREATMENTS IN FIELD B

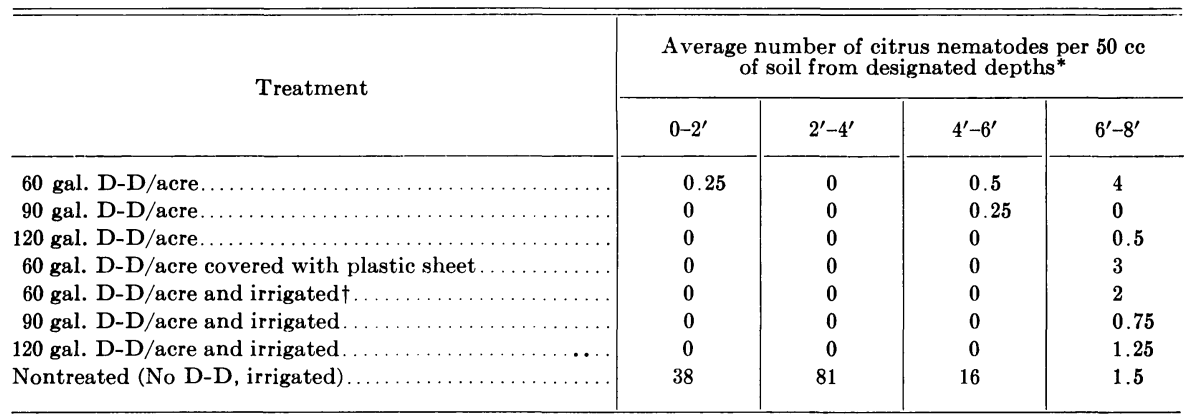

* The figures are the average for four plots.

$\dagger$ Approximately 10 acre-inches of water were applied in furrows two weeks after the D-D.

\section{INFLUENCE OF DEPTH OF INJECTION OF D-D ON THE PATTERN OF DIFFUSION}

A number of workers (Goring, Hanson, Schmidt, and Siegel) have shown that poor control of nematodes near the soil surface results from rapid diffusion of nematocidal vapors to the atmosphere. Both dose and depth of placement of the chemical should influence the concentration of the toxicant near the surface of the soil, and also at deeper depths. In the following test the depth at which D-D was injected was related to control of the citrus nematode.

A Yolo loam in field C, which contained 19.1 per cent clay, 52.6 per cent silt, and 28.3 per cent sand in the top 5 feet of soil (table 3 ) was tilled 7 inches deep. Then 120 gallons of D-D per acre were injected at depths of 12 , $18,24,30$, and 36 inches. The chemical was injected at loci 18 inches apart with hand-operated probe type of applicators on May 24, 1955. Each plot was 9 feet square and the treatments were replicated five times. The moisture content of the top 4 feet of soil was approximately 16 per cent or 5 to 6 per cent less than "field capacity" at the time the treatments were applied. The temperature of the soil did not change greatly during the test. During the first month the average temperature at the 1-, 2-, 3-, and 4-foot depths was $20.4^{\circ} \mathrm{C}, 19.1^{\circ} \mathrm{C}, 18.3^{\circ} \mathrm{C}$, and $18.1^{\circ} \mathrm{C}$, respectively. The number of citrus 
TABLE 8

EFFECT OF DEPTH OF INJECTION OF D-D ON CONTROL OF THE CITRUS NEMATODE IN FIELD C

\begin{tabular}{|c|c|c|c|c|c|c|c|c|}
\hline \multirow{2}{*}{ Depth injected* } & \multicolumn{8}{|c|}{ Average number of larvae per $50 \mathrm{cc}$ of soil from different depths in feet $\dagger$} \\
\hline & $0-1$ & $1-2$ & $2-3$ & $3-4$ & $4-5$ & $5-6$ & $6-7$ & $7-8$ \\
\hline (inches) & & & & & & & & \\
\hline Untreated. & $3,998^{\mathrm{a}} \downarrow$ & $3,756^{\mathrm{a}}$ & $2,615^{\mathrm{a}}$ & $1,345^{\mathrm{a}}$ & $434^{a}$ & $215^{\mathrm{a}}$ & 58 & 10 \\
\hline 12. & $0^{\mathrm{b}}$ & $0^{\mathrm{b}}$ & $0^{\mathrm{b}}$ & $38^{\mathrm{b}}$ & $767^{\mathrm{a}}$ & $341^{\mathrm{a}}$ & 134 & 58 \\
\hline 18. & $27^{\mathrm{b}}$ & $0^{\mathrm{b}}$ & $0^{\mathrm{b}}$ & $6^{\mathrm{b}}$ & $230^{\mathrm{ab}}$ & $406^{\mathrm{a}}$ & 37 & 40 \\
\hline 24 . & $137^{\mathrm{c}}$ & $0^{\mathrm{b}}$ & $0^{\mathrm{b}}$ & $0^{c}$ & $7^{b}$ & $8 j^{\mathrm{ab}}$ & 23 & 31 \\
\hline $30 \ldots$ & $623^{\circ}$ & $0^{\mathrm{b}}$ & $0^{\mathrm{b}}$ & $0^{\mathrm{c}}$ & $0^{c}$ & $11^{\mathrm{b}}$ & 113 & 4 \\
\hline $36 \ldots$ & $846^{\mathrm{c}}$ & $0^{\mathrm{b}}$ & $0^{\mathrm{b}}$ & $0^{\mathrm{c}}$ & $0^{\mathrm{c}}$ & $3^{\mathrm{b}}$ & 37 & 6 \\
\hline
\end{tabular}

*The D-D was injected with "Mack" Chemical Injectors at 18 inches spacing between points of injection, on May 24, 1955. Soil samples for determination of live nematodes were taken on August 9 to $24,1955$.

$t$ The figures are the average for five replications.

$\ddagger$ A separate statistical analysis was made for each depth. The superscripts indicate populations at the 0.01 level of probability. Different letters indicate that the mean differences are highly significant; similar letters indicate that the mean differences are not significant.

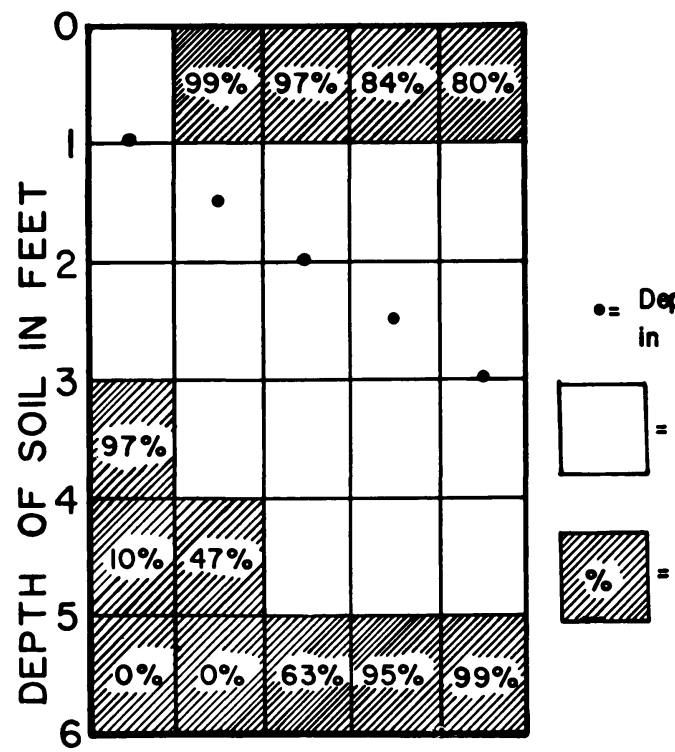

Depth that D-D was placed in the soil $=100 \%$ Control

\section{Numbers designate per- cent of the cltrus nematodes killed}

Fig. 4. Type of control of the citrus nematode obtained when 120 gallons of D-D per acre were applied at depths of $12,18,24,30$, and 36 inches in a Yolo loam soil.

nematodes in the soil at different depths was determined 10 to 12 weeks after treating and is presented in table 8 and figure 4 .

All of the citrus nematodes were killed in the first 3 feet of soil and 97 per eent in the fourth foot when D-D was injected 12 inches deep. When D-D was placed 18 inches deep, 99 per cent of the nematodes were killed in the first foot, 100 per cent in the second, third, and fourth foot, and 47 per cent in 
the fifth foot. With increased depth of injection higher percentages of the nematodes survived in the first foot of soil and control extended to deeper depths, as shown in figure 4 . When D-D was applied 24 inches deep, 100 per cent of the citrus nematodes were killed in the first foot above the depth of injection, and 97 per cent in the next, or surface, foot. However, 100 per cent of the nematodes were killed in the zone 2 feet below the depth of placement, and 98 per cent in the next foot deeper. When injected 36 inches deep, 100 per cent of the citrus nematodes were killed in the first and second foot and 80 per cent in the third foot of soil above the depth of placement. All of the citrus nematodes also were killed in the first and second foot below the depth of placement and 99 per cent in the third foot. Thus, when the D-D was injected 30 inches and 36 inches deep all of the citrus nematodes in a band of soil 4 feet deep were killed, and between 80 per cent and 99 per cent of the nematodes were killed in another 2-foot depth of soil.

It appeared that D-D diffused downward farther than it did upward. This may be due to loss of the chemical from the surface of the soil and thus to lower concentrations of the chemical in the zone near the surface. The per cent of nematodes killed at lower depths in the soil was related directly to depth of placement of the chemical. While it is recognized that the physical properties of soil affect the diffusion of $\mathrm{D}$-D, the diffusion patterns obtained in this test do not appear to have been affected greatly by changes of the soil at different levels. However, the 7 inches of tilled soil at the surface very likely affected the concentration of D-D in the first foot of soil.

Maximum control apparently had occurred when sampled three months after treating, for similar patterns of control were obtained when the 18inch- and 30-inch-depth treatments were sampled again after six months.

\section{POST-IRRIGATION, SEASON OF YEAR, AND DEPTH APPLIED}

A series of tests were made to obtain further information on the effect of the following treatments: 1 ) depth of placement of D-D ; 2) post-irrigation; and 3 ) time of year treated (soil temperature and possibly climatic factors), on control of the citrus nematode. One hundred twenty gallons of D-D per acre were applied 9 and 14 inches deep by chisels spaced 20 inches apart. The soil was then cultipacked twice. Supplemental treatments consisting approximately of 1 acre-inch of water by overhead irrigation and 5 to 6 acreinches of water in shallow furrows were applied 20 to 24 hours after the D-D was placed in the soil. All of the treatments were applied at three different periods: March 3 and 4, July 7 and 8, and November 10 and 11, 1954, on a Yolo silt loam soil in field D. This soil contained 27.2 per cent clay, 53.4 per cent silt, and 19.4 per cent sand in the top 5 feet (table 4 ). Prior to treating, it was chiseled to a depth of 14 inches and the surface 5 to 6 inches tilled to seedbed condition. Each plot was 10 feet by 20 feet in size. Similar postirrigation treatments were arranged in blocks and replicated three times. Weeds were controlled by a single shallow cultivation; thus changes in soil moisture during the period that the tests were made resulted chiefly from 
soil surface evaporation. The moisture content of the first foot of soil was approximately 3 per cent below field capacity in March and 5 per cent below field capacity in July. The surface foot of soil was wet by a light rain in November, and was approximately 6 per cent below field capacity at the time of application of the chemical (table 9 ).

Slightly better control was obtained when D-D was applied 14-inches deep than 9-inches deep in all tests, except the furrow-irrigated treatments in November (table 10). Control was not affected when the surface 8 to 10

TABLE 9

SOIL MOISTURE AND TEMPERATURE DATA FOR FIELD D

\begin{tabular}{|c|c|c|c|}
\hline \multirow{2}{*}{ Depth } & \multicolumn{3}{|c|}{ Water contained in the soil } \\
\hline & $3 / 2 / 54$ & $7 / 8 / 54$ & $11 / 10 / 54$ \\
\hline (feet) & (per cent) & (per cent) & (per cent) \\
\hline \multirow{4}{*}{$\begin{array}{l}0-2 \ldots \\
2-4 \ldots\end{array}$} & 18.0 & 15.0 & 15.1 \\
\hline & 24.0 & 21.0 & 20.1 \\
\hline & \multicolumn{3}{|c|}{ Average soil temperature, ${ }^{\circ} \mathrm{F}$} \\
\hline & $3 / 1-3 / 14$ & $7 / 7-7 / 21$ & $11 / 10-11 / 24$ \\
\hline \multirow{2}{*}{$\begin{array}{l}1 . . \\
2 .\end{array}$} & 57.1 & 78.4 & 63.3 \\
\hline & 58.7 & 73.1 & 63.3 \\
\hline 4. & 50.0 & 70.0 & 66.0 \\
\hline
\end{tabular}

inches of soil were wet after applying the D-D. In three of the six furrowirrigated treatments, control in the surface foot of soil was superior to, and in three cases it was equal to that obtained by cultipacking the soil. Furrow irrigation also improved control in the subsoil in all cases. The increased control resulting from furrow irrigation apparently is not due solely to wetting the surface of the soil, since sprinkling with 1 inch of water accomplished that, but did not improve control. The thorough wetting and usual settling of the soil during furrow irrigation probably increased the bulk density of the top 14 inches of soil, which had been loosened by working. This would retard escape of D-D vapor to the atmosphere. Also, dissolved D-D would be carried downward with the water.

Best control was obtained when the D-D was applied by the different methods on November 11 and 12, with one exception, which consisted of the D-D applied 14 inches deep and then furrow-irrigated in July. When this treatment was applied on July 7 and 8, and November 10 and 11, control was essentially the same. The differences in the efficacy of the treatments made in March, July, and November may be due to differences in the rate of loss of D-D from the soil surface. In March and July the surface of the soil appeared to dry more rapidly than in November and this likely accelerated the diffusion of D-D vapor to the atmosphere. Soil temperature and possibly soil moisture on the different dates of application (table 9) may have affected 
the diffusion of D-D. On March 3, the top 24 inches of soil contained 18 per cent moisture, which was slightly less than "field capacity," and the 24inch and 48-inch horizon, 24 per cent moisture (approximately field capacity). The soil moisture at both depths was slightly less than "field capacity" on July 7 and November 11. Thus, it does not appear likely that the slight changes in moisture content of this well-drained soil affected the diffusion of the D-D, especially when one considers that the 1 acre-inch of

TABLE 10

CONTROL OF THE CITRUS NEMATODE WITH 120 GALLONS OF D-D PER ACRE APPLIED IN THE SPRING, SUMMER, AND FALL BY DIFFERENT METHODS*

\begin{tabular}{|c|c|c|c|c|c|c|c|}
\hline \multirow[b]{2}{*}{$\begin{array}{c}\text { Date } \\
\text { treated }\end{array}$} & \multirow[b]{2}{*}{$\begin{array}{c}\text { Depth } \\
\text { sampled }\end{array}$} & \multicolumn{3}{|c|}{ Applied $9^{\prime \prime}$ deep $\dagger$} & \multicolumn{3}{|c|}{ Applied $14^{\prime \prime}$ deep $\dagger$} \\
\hline & & Cultipacked & $\begin{array}{l}\text { Cultipacked } \\
\text { and } \\
\text { sprinkled }\end{array}$ & $\begin{array}{l}\text { Cultipacked } \\
\text { and furrow- } \\
\text { irrigated } \ddagger\end{array}$ & Cultipacked & $\begin{array}{c}\text { Cultipacked } \\
\text { and } \\
\text { sprinkled }\end{array}$ & $\begin{array}{l}\text { Cultipacked } \\
\text { and furrow- } \\
\text { irrigated } \ddagger\end{array}$ \\
\hline & (feet) & (per cent) & (per cent) & (per cent) & (per cent) & (per cent) & (per cent) \\
\hline \multirow[t]{3}{*}{ March $3,4 \ldots \ldots$} & $0-2$ & 99 & 88 & 100 & 100 & 100 & 100 \\
\hline & $2-4$ & 23 & 28 & 94 & 95 & 61 & 99 \\
\hline & $4-6$ & 0 & 0 & 0 & 0 & 22 & 20 \\
\hline \multirow[t]{3}{*}{ July $7,8 \ldots \ldots \ldots$} & $0-2$ & 96 & 83 & 100 & 99 & 100 & 100 \\
\hline & $2-4$ & 60 & 39 & 98 & 81 & 86 & 100 \\
\hline & $4-6$ & 40 & 0 & 69 & 18 & 32 & 81 \\
\hline \multirow[t]{4}{*}{ Nov. $10,11 \S \ldots .}$. & $0-2$ & 100 & 100 & 100 & 100 & 100 & 100 \\
\hline & $2-4$ & 100 & 100 & 100 & 100 & 100 & 100 \\
\hline & $4-5$ & 3 & 20 & 94 & 35 & 96 & 100 \\
\hline & $5-6$ & 14 & 50 & 81 & 19 & 32 & 85 \\
\hline
\end{tabular}

* The D-D was applied with applicator chisels 20 inches apart.

† The control obtained with D-D applied 14 inches deep is statistically different from that applied 9 inches deep at each date of treatment, at the 0.01 level. This does not apply to differences occurring between the different dates of treatment.

$\ddagger$ Control obtained with the furrow-irrigation treatment is statistically different from the cultipacked, and cultipacked-sprinkled treatments for each date of treating, at the 0.01 level.

\$ The control obtained with the treatments applied on November 10 and 11 is statistically different from similar treatments applied on March 3 and 4, and on July 7 and 8, at the 0.01 level, except that it was similar when D-D was applied 14 inches deep and furrow-irrigated on July 7 and 8 , and on November 10 and 11 . Differences between the control obtained between similar treatments applied on March 3 and 4 and July 7 and 8 are not significant.

water applied. by sprinkling wet the top foot of soil, and the 5 to 6 acreinches of water applied by furrows brought the soil to a depth of 8 or more feet to field capacity.

It is possible that temperatures of $57^{\circ} \mathrm{F}$ and $78^{\circ} \mathrm{F}$ at the 12 -inch depth are not so favorable for control with $\mathrm{D}-\mathrm{D}$ as $63^{\circ} \mathrm{F}$. At $78^{\circ} \mathrm{F}$ the vapor pressure of the D-D would be slightly higher than at $63^{\circ} \mathrm{F}$, which might result in more rapid diffusion from the soil, and thus the attainment of low concentrations near the surface. At $57^{\circ} \mathrm{F}$ the vapor pressure of $\mathrm{D}-\mathrm{D}$ is less than at $63^{\circ} \mathrm{F}$ and it would diffuse more slowly toward the surface and thus might not reach high concentrations, especially near the surface. The volume of D-D vapor was not greatly affected by the temperature of the soil during these tests, since at $57^{\circ} \mathrm{F}$ the $\mathrm{D}-\mathrm{D}$ vapors would occupy 4 per cent less volume than at $78^{\circ} \mathrm{F}$. 


\section{POST-IRRIGATION WITH DIFFERENT AMOUNTS OF WATER}

In the above test the effectiveness of D-D was increased when approximately 6 acre-inches of water were applied by furrows. The effects of larger amounts of water on control with D-D were determined in the following test. Basins 10 feet square were made on a soil similar to that of the previous test and described in table 4 . Then $\mathrm{D}-\mathrm{D}$ at a rate of 120 gallons per acre was applied with a probe applicator inside the basins. It was injected 10 inches deep at loci 17 inches apart and the probe holes were closed by pressing the soil.

TABLE 11

EFFECT OF DIFFERENT AMOUNTS OF WATER ON CONTROL OF THE CITRUS NEMATODE WITH D-D

\begin{tabular}{|c|c|c|c|c|c|}
\hline \multirow{2}{*}{ Treatment } & \multirow{2}{*}{$\begin{array}{l}\text { Depth } \\
\text { of water } \\
\text { applied, } \\
\text { in inches }\end{array}$} & \multicolumn{4}{|c|}{ Number of larvae per $50 \mathrm{cc}$ of soil from different depths* } \\
\hline & & $0-2^{\prime}$ & $2^{\prime}-4^{\prime}$ & $4^{\prime}-6^{\prime}$ & $6^{\prime}-8^{\prime}$ \\
\hline 120 gal. D-D/acre. . & 0 & $0 \mathrm{a}$ & $0^{\mathbf{a}}$ & $12^{\mathrm{a} \dagger}$ & 69 \\
\hline 120 gal. D-D/acre........ & 6 & $0^{\mathrm{a}}$ & $0^{\mathrm{a}}$ & $17 \mathrm{a}$ & 7 \\
\hline 120 gal. D-D/acre.. & 12 & $0^{\mathrm{a}}$ & $0^{\mathrm{a}}$ & $7 \mathrm{a}$ & 34 \\
\hline 120 gal. D-D/acre. . & 18 & $0^{\mathrm{a}}$ & $0^{\mathrm{a}}$ & $7 \mathrm{a}$ & 24 \\
\hline Nontreated....... & 0 & $478^{b}$ & $315^{\mathbf{b}}$ & $168^{\mathrm{b}}$ & 113 \\
\hline
\end{tabular}

* The numbers are the average for four plots. tion.

$\dagger$ The letters designate statistically different groups at the 0.01 level. See footnote table 8 for further informa-

Approximately 18 hours later 6, 12, and 18 acre-inches of water were applied. The experimental design consisted of four blocks of randomized plots.

All of the citrus nematodes in the top 4 feet of soil, and 90 to 96 per cent of those in the 4- to 6-foot horizon were killed on all of the plots that were treated with D-D (table 11). The application of 6,12 , and 18 acre-inches of water had no apparent effect on control with the D-D in this experiment. D-D vapors would be expected to escape slowly from the surface soil in this test, since the soil was disturbed slightly with the probe applicator. The effect of irrigation on the surface seal and rate of loss of $D-D$ vapors from the soil surface could not be estimated in this test, since the nonirrigated D-D treatment also effectively controlled the nematodes in the surface soil. However, the data indicate that irrigation did not move lethal amounts of D-D to depths beyond the normal diffusion pattern for this soil.

Cracks developed in the soil of the irrigated plots five to six days after treating and may have adversely affected the control. However, the soil surface was re-wet by rains three weeks after treating. The cracks did not appear to have affected control of the nematode greatly, since all of the citrus nematodes in the first foot of soil were killed on both the irrigated and nonirrigated plots which had been treated with D-D.

The moisture content of the 0 to 48 -inch depth of soil was increased from 11.7 per cent to approximately 23 per cent (field capacity) by irrigation with 
12 inches and 18 inches of water. Thus, the D-D appeared to diffuse similarly in a vertical direction in this Yolo loam at 11.7 per cent and at 23 per cent moisture. In other words, it diffused as readily in the greater volume of water and less air of the wet soil as in the dry soil, which contained less water and more air. The irrigation treatments saturated the surface 4 to 5 inches for only a short period and increased the moisture content of the soil below to field capacity.

\section{MOVEMENT OF D-D BY WATER}

In the above tests water was applied approximately one day after the chemical was placed in the soil. It was conceivable that control might be improved by applying water after longer periods. With longer periods of time between D-D placement and irrigation, D-D vapors should diffuse into a larger mass of soil and thus more readily dissolve in water moving through the soil. In the following tests water was applied at different periods to obtain additional information on the diffusion pattern in moist soil and movement of D-D by water.

D-D at the rate of 120 gallons per acre was injected 11 to 12 inches deep in a Yolo loam soil in field $\mathrm{C}$ (table 3 ) by means of chisels 29 inches apart. This distance between the injection streams of D-D facilitated evaluation of the effect of irrigation treatments on the diffusion of D-D laterally through this soil. Duplicate plots $10 \times 60$ feet in size were treated with D-D 7, 3, 1, and 0 days before irrigation. Soon after applying the D-D the soil surface was cultipacked four or more times and remained so until furrows were made just prior to irrigating. Shallow furrows, into which water was run for 45 hours, were made over the D-D injection euts. It was estimated that 18 to 20 acre-inches of water infiltrated into the soil. Soil samples for determination of nematodes were taken on the injection bands and also middistance between the bands 2.5 months after treating.

On the nonirrigated D-D treated plots 99.9 per cent, 100 per cent, 99.6 per cent and 91 per cent, respectively, of the citrus nematodes in the first-, second-, third-, and fourth-foot depths of soil, mid-distance between the D-D injection bands, were killed (table 12). On the plots that were irrigated 0 , 1, and 3 days after applying the D-D, 94 per cent, 95 per cent, and 97 per cent, respectively, of the citrus nematodes in the first foot of soil midway between the D-D injection bands, were killed. Between 99.7 per cent and 99.9 per cent of the citrus nematodes were killed at the 1- to 4-foot depth, and between 83 per cent and 91 per cent in the fifth foot of soil. However, in the soil taken on the D-D injection bands all of the citrus nematodes between the surface and the 4-foot depth were killed. When water was applied seven days after the D-D, all of the citrus nematodes were killed to a depth of 4 feet both midway between, and on the D-D injection bands, and 94 per cent in the fifth foot midway between, and 100 per cent on the D-D injection bands.

The high moisture content of the soil when irrigated 0 , one, and three days after applying the D-D, apparently limited its movement, especially through the first foot of soil. When water was applied seven days after the D-D, suf- 
ficient concentration of D-D vapor to kill all of the citrus nematodes in the first foot of soil apparently had diffused laterally and vertically 18.8 inches from the D-D injection bands. The water likely carried considerable amounts of D-D to lower depths in the soil and thus increased control at the 3- to 5 -foot depths. The pattern of kill suggests that the D-D diffused rather slowly through this soil and that the water moved it chiefly downward and to a limited extent, laterally. The concentration of D-D in the water must have been decreased by adsorption on the soil; otherwise the nematodes would

TABLE 12

EFFECT OF IRRIGATION AT VARIOUS PERIODS AF́TER APPLYING D-D

\begin{tabular}{|c|c|c|c|c|c|c|c|}
\hline \multirow{2}{*}{$\begin{array}{l}\text { Days between } \\
\text { applying D-D and } \\
\text { irrigation* }\end{array}$} & \multirow{2}{*}{ Area sampled } & \multicolumn{6}{|c|}{$\begin{array}{c}\text { Average number of citrus nematode larvae per } 50 \mathrm{cc} \\
\text { of soil from depths indicated } \dagger\end{array}$} \\
\hline & & $0-1^{\prime}$ & $1^{\prime}-2^{\prime}$ & $2^{\prime}-3^{\prime}$ & $3^{\prime}-4^{\prime}$ & $4^{\prime}-5^{\prime}$ & $5^{\prime}-6^{\prime}$ \\
\hline No irrigation. & Between the D-D bands & 7 & 0 & 12 & 129 & 205 & 119 \\
\hline $0 \ldots \ldots$ & Between the D-D bands & 488 & 6 & 9 & 22 & 97 & 172 \\
\hline $1 \ldots$ & Between the D-D bands & 508 & 8 & 1 & 3 & 51 & 298 \\
\hline 3. & Between the D-D bands & 235 & 4 & 1 & 1 & 67 & 55 \\
\hline 7.. & Between the D-D bands & 0 & 0 & 0 & 0 & 34 & 548 \\
\hline 0 . . & On the D-D band & 0 & 0 & 0 & 0 & 1,036 & 202 \\
\hline $1 .$. & On the D-D band & 0 & 0 & 0 & 0 & 8 & 44 \\
\hline $3 .$. & On the D-D band & 0 & 0 & 0 & 0 & 2 & 51 \\
\hline $7 \ldots \ldots \ldots \ldots$ & On the D-D band & 0 & 0 & 0 & 0 & 0 & 18 \\
\hline $\begin{array}{l}\text { Nontreated (Irrigated } \\
\text { only) } \ldots \ldots \ldots \ldots \ldots\end{array}$ & & 7,725 & 9,300 & 3,225 & 1,433 & 555 & 750 \\
\hline
\end{tabular}

* 120 gallons of D-D per acre were applied 11 to 12 inches deep by chisels 29 inches apart.

t Soil samples for determining citrus nematodes were taken 10 weeks after treating. The samples were taken on the chisel cuts (D-D bands) made when applying the D-D and also mid-distance between the chisel cuts.

have been killed at lower depths, since 18 acre-inches of water wet the soil to a depth of 9 or more feet.

The effects of post-irrigation on the diffusion of D-D were determined on another loam soil in field B (table 2). This soil contained 5.4 per cent less clay than the soil in above test. D-D was applied at rates of 60,90 , and 120 gallons per acre and at a depth of 14 inches by means of chisels 22 inches apart. The soil was cultipacked twice immediately after applying the chemical. Two weeks later furrows were made and water was run in the furrows for 24 hours. It was estimated that 9 to 10 acre-inches of water infiltrated the soil. The plots were 24 feet square and the experimental design consisted of four randomized blocks. The number of citrus nematodes in the 0 to 8 -foot depth of soil, three months after treating, are presented in table 7.

When 60 gallons of D-D per acre were applied, 99 per cent, 100 per cent, and 97 per cent, respectively, of the citrus nematodes in the 0 to 2 -foot, 2 - to 4-foot, and 4- to 6-foot depths were killed. All of the citrus nematodes in the top 4 feet of soil and 98 per cent of those in the 4- to 6-foot horizon were killed when 90 gallons of D-D were applied. On the plots treated with 120 gallons of D-D per acre, all of the citrus nematodes in the top 6 feet of soil were killed. When the D-D treated plots were irrigated two weeks after treating, all of the citrus nematodes in the top 6 feet of soil were killed. In this 
test the irrigation increased the effectiveness of the 60- and 90-gallons-peracre treatments, but did not improve the control when 120 gallons of D-D per acre were applied. None of the treatments apparently killed the nematodes in the 6 - to 8-foot depth. It appeared that the water did not penetrate and move the D-D deeper than 6 feet in this soil. When 60 gallons of D-D per acre were applied and irrigated, control was equal to that when 120 gallons of D-D per acre were applied. This suggests that if more water had infiltrated the soil, control of the nematodes at depths below 6 feet would likely have been improved.

\section{DIFFUSION OF D-D IN DRY AND MOIST SOIL}

Frequently D-D is applied in the field when the surface soil is moist and the subsoil is relatively dry. Such soil moisture conditions may be favorable for diffusion of D-D vapor and thus control of the citrus nematode. The efficacy of D-D for control of the citrus nematode in a Yolo loam soil in field E (table

TABLE 13

PER CENT CONTROL OF THE CITRUS NEMATODE WITH D-D APPLIED ON A LOAM SOIL IN FIELD E AT TWO LEVELS OF SOIL MOISTURE*

\begin{tabular}{|c|c|c|c|c|}
\hline \multirow{2}{*}{ Depth } & \multicolumn{2}{|c|}{ Dry soil } & \multicolumn{2}{|c|}{ Moist soil } \\
\hline & Water in soil & Control & Water in soil & Control \\
\hline (feet) & (per cent) & (per cent) & (per cent) & (per cent) \\
\hline $0-2 \ldots \ldots$ & 8.5 & 100 & 15.5 & 100 \\
\hline $2-4 \ldots \ldots \ldots \ldots \ldots$ & 8.3 & 100 & 16.9 & 100 \\
\hline $4-6 \ldots \ldots \ldots \ldots \ldots$ & 7.6 & 99 & 17.3 & 88 \\
\hline
\end{tabular}

* 120 gallons of D-D per acre were applied 12 inches deep by chisels 18 inches apart.

5 ) at two levels of soil moisture was determined. Plots at two levels of soil moisture were established in the open areas between rows of orange trees. The dry area was irrigated four months before and the wet area two weeks before application of the D-D. The soil moisture was partially depleted by the orange trees. A light rain just prior to the test moistened the top 9 inches of soil, which facilitated tillage of the surface 10 inches, and also resulted in similar compaction of the surface soil after the D-D was applied. The top 6 feet of dry soil contained an average of 8.1 per cent moisture, which was close to the wilting point, and the wet soil an average of 16.5 per cent moisture, which was 2 to 3 per cent below the field capacity. On November 10 , 1955, 120 gallons of D-D per acre were applied 12 inches deep by chisels which were 18 inches apart. Each plot was $12 \times 40$ feet in area and the treatments were duplicated. The numbers of citrus nematodes obtained at various depths in the soil five months after treating are presented in table 13.

All of the citrus nematodes were killed to a depth of 4 feet at both soil moisture levels. At the 4- to 6-foot horizon, 99 per cent of the citrus nema- 
todes were killed in the dry soil and 88 per cent in the wet soil. Thus, D-D moved slightly farther in this loam soil when it contained 8.1 per cent moisture than when it contained 16.5 per cent.

\section{EFFECT OF DIFFERENT DEPTHS OF PLACEMENT AND OF DISTANCES BETWEEN D-D BANDS ON CONTROL}

In the earlier tests (table 10), 120 gallons of D-D per acre applied 14 inches deep by means of chisels controlled the citrus nematode better than when it was placed 9 inches deep in a Yolo loam soil. In another test (table 8), more nematodes were killed in the subsoil when D-D was applied at depths of 18

TABLE 14

CONTROL OF THE CITRUS NEMATODE BY 120 GALLONS OF D-D PER ACRE APPLIED AT DIFFERENT DEPTHS AND DISTANCES BETWEEN THE BANDS ON A YOLO LOAM SOIL

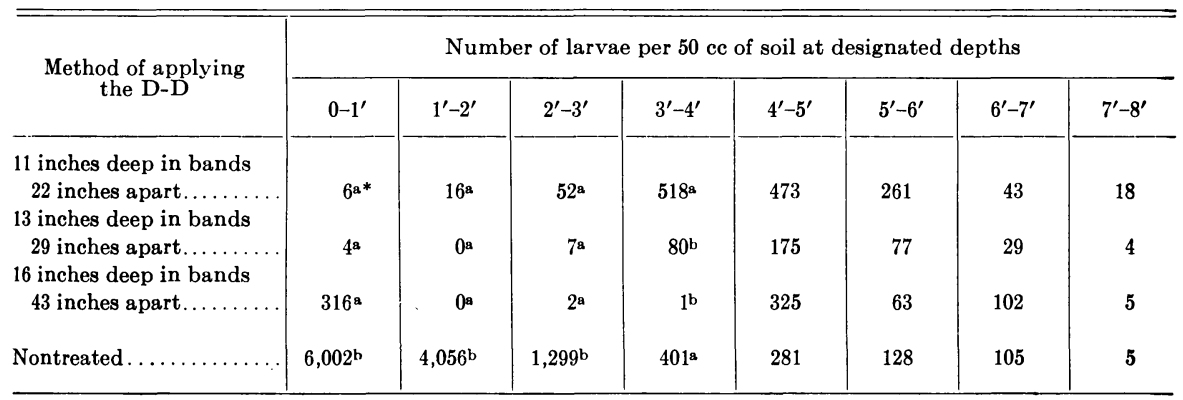

* The letters designate populations at each depth in the soil which are statistically different at the 0.01 level. See footnote table 8 for further explanation.

inches or 24 inches than at 12 inches with hand-operated equipment. However, fewer nematodes were killed in the surface foot of soil when the depth of placement of D-D was increased. Since considerably more power is required to pull chisels at depths of 14 inches or more through soil than at depths of 9 to 10 inches, it appeared important to determine the effectiveness of D-D applied at different distances between the bands and at different depths by power equipment. This might result in more economical use of power, since for each foot traveled a larger area would be treated when the chisels are spaced wider apart.

The loam soil in field $\mathrm{C}$ (table 3 ) was tilled to a depth of 8 to 9 inches. Then D-D at the rate of 120 gallons per acre was applied at a depth of 11 inches by chisels 22 inches apart, and at a depth of 13 inches by chisels 29 inches apart, and also at a depth of 16 inches by chisels 43 inches apart. After applying the D-D on May 27, 1955, the surface was cultipacked four times. Each plot was $9 \times 20$ feet in size and the experimental design consisted of five randomized blocks. The numbers of citrus nematodes in the soil mid-distance between the D-D bands three months after treating, and also on the nontreated plots are presented in table 14. 
The D-D applied in bands 22 inches apart and 11 inches deep killed 99.9 per cent, 99.6 per cent, and 95.9 per cent of the citrus nematodes in the first, second, and third foot of soil. When it was applied in bands 29 inches apart and 13 inches deep, 99.9, 100, 99.4, and 80 per cent, respectively, of the nematodes in the 1- to 4-foot depths of soil were killed. Fewer nematodes in the first foot of soil were killed when the D-D was applied in bands 43 inches apart and 16 inches deep than in the above treatments. However, a higher per cent of those in the soil at the fourth foot were killed. Best control was obtained when the D-D was applied in bands 29 inches apart and 13 inches deep, and next best when applied in bands 43 inches apart and 16 inches deep. If the soil had been tilled deeper than 9 inches prior to applying the D-D, more of the nematodes in the first foot of soil probably would have been killed by all the treatments.

\section{DISCUSSION}

In many cases control measures are directed toward the nematodes in the top 18 to 24 inches of soil. This is especially so when nematode-susceptible annual crops are to be grown. When the surface 10 or more inches of soil are in good tilth, nematocides usually quickly disperse throughout the surface soil and effectively control the nematodes in the surface foot or two of soil. When nematode-susceptible perennial crops are to be grown it is especially important that nematodes in the subsoil as well as in the surface layers be controlled. In such cases it usually is necessary that the nematocide, either dissolved in water or as a vapor, diffuse through a mass of undisturbed soil in order to kill nematodes in the subsoil.

The citrus nematode was a satisfactory test organism for determining the diffusion pattern of D-D in soils. All stages of the nematode occur on the surface of susceptible roots. The heads of mature citrus nematodes usually come to lie just on the outside of the pericycle of rootlets, while the posterior two thirds of the nematode protrudes on the exterior of the root. The females lay eggs in a gelatinous-like material which soon encases the females. Large numbers of citrus nematode larvae usually occur in soils cropped to citrus and on those from which citrus trees have been removed recently. Also, the young nematodes do not move far in the soil and are sensitive to D-D. A concentration of $10 \mathrm{ppm}$ of D-D in loam soils usually is equivalent to $95 \mathrm{LD}$.

Covering the surface of a loam soil with a polyethylene-vinyl-plastic tarp after 60 gallons of D-D per acre had been placed 14 inches deep in the soil gave better control of the citrus nematode in the top 6 feet of soil than cultipacking the surface thoroughly. This illustrates the relative degree of effectiveness of such operations and the importance of thoroughly rolling the surface of the soil after applying D-D and other volatile chemicals, especially when the objective is to obtain diffusion of the vapors to deep depths in the soil. Compressing the surface of the soil apparently also is important when a shallow type of control is desired. Thus, Allen and Raski (1950) showed that the root-knot nematodes in the surface 3 to 4 inches of soil frequently survived when D-D was applied, and Goring (1957) when ethy- 
lene dibromide was applied, because of rapid loss of the vapors to the atmosphere. In the treatment of fields for control of nematodes the surface soil frequently is compressed so little after the D-D has been applied that, as a consequence, the D-D escapes rapidly to the atmosphere, giving relatively poor control.

Applying 1 acre-inch of water by sprinklers the day after 120 gallons of D-D per acre had been placed in bands 20 inches apart and 9 and 14 inches deep in a loam soil, with the surface then cultipacked did not improve control. However, 6 to 18 acre-inches of water applied by furrows after the D-D had been placed in the soil increased control of the citrus nematode. When the D-D bands were 29 inches apart, water applied seven days after the D-D increased control of the citrus nematode more than when applied after 0,1 or 3 days. Apparently wetting the surface soil impaired slightly the diffusion of D-D through the loam soil in field $\mathrm{C}$, but during the seven-day period between applying the $\mathrm{D}-\mathrm{D}$ and irrigation nematocidal concentrations of the D-D had diffused through the surface soil before the water was applied. However, when the D-D bands were 18 or 20 inches apart, all of the nematodes in the surface foot of soil were killed when the soil was wet to "field capacity" soon after applying 120 gallons of D-D per acre.

A number of factors should be considered in evaluating the effect of depth of placement of the D-D on control of the citrus nematode on Yolo loam soils. It usually is accepted that the vapor pressure of D-D is highest around the loci of placement of the chemical in a soil. Also, that movement of the vapors will be toward the points of least concentration of the D-D, provided no barriers interfere with its movement. The rate of loss of the chemical from the surface of the soil thus would affect the concentration both in the surface soil and in the subsoil, since a gradient would be established toward the surface and less of the chemical would diffuse into the subsoil. Even though loss of D-D from the surface soil may be slow, it affects the amount which diffuses into the subsoil, as shown in table 7. In evaluating the loss from the soil surface, it should be kept in mind that movement of D-D through undisturbed loam soils is slow, as illustrated in figure 3. Thus, treatments such as rolling the surface of the soil, covering with a gas-proof tarp, and depth of placement of the chemical in the soil, affected the type of control obtained. Factors such as temperature of the surface soil, air movement, and condition of the soil would also influence the rate of loss of D-D. Best control in the first foot of soil was obtained when 120 gallons of D-D per acre were applied 12 inches deep on a Yolo loam soil (table 8). In this test the surface soil had been tilled to a depth of 7 inches. However, when D-D was applied 9 and 14 inches deep by means of a chisel type applicator on a loam soil which had been tilled 14 inches deep, best control was obtained with the deeper placement (table 10).

Post-irrigation on well-drained soils resulted in more effective use of the chemical. This might be an economical practice when water is available and the land can be irrigated easily. Thus, the nematode-control pattern was similar when 60 gallons of D-D were applied per acre and irrigated or when 120 gallons per acre were applied and not irrigated. 
D-D diffused progressively less in two loam soils and a silt loam soil which contained 13.7 per cent clay (field B), 17.9 per cent clay (field E), and 27.2 per cent clay (field D). This is in agreement with earlier investigations by Allen and Raski (1950) who reported that D-D was about 100 times more effective when applied on a sandy loam than on a clay loam soil.

Since 120 gallons of D-D applied 14 inches deep on Yolo silt loam and loam soils may not kill all of the citrus nematodes occurring below 4 feet in the soil, higher doses of the chemical and also post-irrigation should be used in order to obtain control of the citrus nematodes occurring in the top 6 to 8 or more feet of soil.

\section{SUMMARY}

The vertical diffusion pattern and efficacy of D-D in Yolo loam and silt loam soils under field conditions were determined. In a number of tests doses of 120 to 180 gallons of D-D per acre killed 100 per cent of the citrus nematodes in the top 4 to 5 feet of soil.

Ten acre-inches of water applied 14 days after 120 gallons of D-D per acre had been applied in bands 20 inches apart, increased control of the citrus nematode. Also, 18 acre-inches of water applied seven days after the D-D had been applied in bands 29 inches apart, increased greatly the control of the citrus nematodes in the top 4 feet of soil. When 6,12 , or 18 acreinches of water were applied one day after the D-D had been placed in the soil in bands or at injection loci 18 or 20 inches apart, control in some tests was increased slightly, and in others there was no apparent effect. However, when the bands of D-D were 29 inches apart, 18 acre-inches of water applied 0, 1, or 3 days after the D-D decreased control in the top foot of soil.

Soil moisture between the wilting point and field capacity had little effect on diffusion of D-D in two fine-textured Yolo loam soils.

Wetting the surface foot of soil after D-D had been placed 9 or 14 inches deep, did not improve control above that obtained by thoroughly cultipacking or rolling the surface.

Slightly superior control of the citrus nematode occurred when 120 gallons of D-D per acre were applied in November than in March or July.

Superior citrus nematode control was obtained when 120 gallons of D-D per acre were applied 14 inches deep than when applied 9 inches deep by a tractor applicator. The control of the citrus nematode in the surface foot of soil decreased when depth of placement was increased from 12 to 36 inches in a soil which had been tilled shallowly. However, control at lower depths improved with increased depth of injection in this soil.

\section{ACKNOWLEDGMENT}

The authors especially acknowledge the coöperation of personnel of the Limoneira Company in making available facilities and some of the equipment used in the tests. 


\section{LITERATURE CITED}

Allen, M. W., and D. J. RASKI

1950. The effect of soil type on the dispersion of soil fumigants. Phytopathology 40: 1043-53.

Baines, R. C., F. J. Foote and J. P. Martin

1956. Fumigate soil before replanting citrus for control of the citrus nematode. Calif. Citrograph $41: 427,448-51$.

DAY, PAUL R.

1950. Physical basis of particle size analysis by the hydrometer method. Soil Sci. 70 : 363-74.

Goring, C. A. I., and C. R. Youngson

1957. Factors influencing nematode control by ethylene dibromide in soil. Soil Sci. 83: $377-89$.

HAGAN, R. M.

1941. Movement of carbon disulfide vapor in soils. Hilgardia 14 (2) :83-118.

HaNnesson, H. A.

1945. Movement of carbon disulfide vapor in soils as affected by soil type, moisture content and compaction. Hilgardia 16(10):503-10.

Hanson, W. J., and Nex, R. W.

1953. Diffusion of ethylene dibromide in soils. Soil Sci. 76:209-14.

Higgins, J. C., and A. G. Pollard

1937. Studies in soil fumigation. II. Distribution of $\mathrm{CS}_{2}$ in soils fumigated under various conditions. Ann. Appl. Biol. 24 :895-910.

Schmidt, C. T.

1947. Dispersion of fumigants through soil. Jour. Econ. Entomol. 40:829-37.

Siegel, J. J., A. E. ERICKson, and L. M. TURK

1951. Diffusion characteristics of 1,3-dichloropropene and 1,2-dibromoethane in soils. Soil Sci. 72:333-40. 

The journal Hilgardia is published at irregular intervals, in volumes of about 600 pages. The number of issues per volume varies.

Subscriptions are not sold. The periodical is sent as published only to libraries, or to institutions in foreign countries having publications to offer in exchange.

You may obtain a single copy of any issue free, as long as the supply lasts; please request by volume and issue number from:

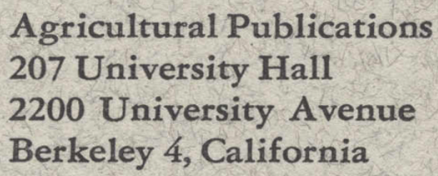

The limit to nonresidents of California is 10 separate issues on a single order. A list of the issues still available will be sent on request.

In our publications it is sometimes convenient to use trade names of products or equipment rather than scientific identifications. In so doing it is unavoidable in some cases that similar products which are on the market under other trade names may not be cited. No endorsement of named products is intended nor is criticism implied of similar products which are not mentioned. 